\title{
The acute toxicity of clove oil to fish Danio rerio and Poecilia reticulata
}

\author{
Petra Doleželová, Stanislava Mácová, Lucie Plhalová, Vladimíra Pištěková, \\ Zdeňka Svobodová
}

Department of Veterinary Public Health and Toxicology, Faculty of Veterinary Hygiene and Ecology, University of Veterinary and Pharmaceutical Sciences Brno, Czech Republic

Received February 22, 2001

Accepted September 13, 2011

\begin{abstract}
Clove oil (active substance eugenol) is an anaesthetic used in aquaculture for stress prevention and prevention of mechanical damage during veterinary procedures. The aim of this study was to determine the acute toxicity of clove oil in two aquarium fish species - zebrafish (Danio rerio) and guppy (Poecilia reticulata), which are considered the most commonly used model organisms in toxicity testing. The semi-static method according to OECD no. 203 (Fish, Acute toxicity test) was used for testing the toxicity of clove oil for juvenile fish. A series of 5 acute toxicity tests was performed, with 10 fish of both species used for each concentration and for the control. The results obtained (number of dead individuals at particular test concentrations) were subjected to a probit analysis using the EKO-TOX 5.2 program in order to determine 96hLC50 clove oil values. The significance of the difference between $96 \mathrm{hLC} 50$ values in D. rerio and P. reticulata was tested using the Mann-Whitney non-parametric test. The 96hLC50 mean value for clove oil was $18.2 \pm 5.52 \mathrm{mg} \cdot 1^{-1}$ in juvenile D. rerio and $21.7 \pm 0.8 \mathrm{mg} \cdot 1^{-1}$ in $P$. reticulata. In spite of variability in clove oil composition, acute toxicity values of clove oil for juvenile stages of both fish species were comparable. The results did not show different sensitivities to clove oil in tested fish species. This is the first similar study in these fish species.
\end{abstract}

Eugenol, anaesthesia, 96hLC50, zebrafish, guppy

The handling and all treatments performed on fish, as well as their transport, must comply with all provisions laid down by Act no. 246/1992 Coll. on the protection of animals against cruelty, as amended. Anaesthesia in fish is used for general sedation in order to enable manipulation and the performance of various veterinary and zootechnical procedures in aquaculture. Anaesthetics are, therefore, used to prevent physical injuries and handling stress during harvesting, sampling and spawning procedures (Kolářová et al. 2006).

An ideal anaesthetic should meet the following criteria: simple administration, rapid induction of anaesthesia, maintenance of the anaesthesia state and rapid recovery, effectiveness at low concentrations, a wide range between effective and toxic concentrations, low tissue residues, and low cost (Marking and Meyer 1985).

The most frequently used anaesthetics in aquaculture in the Czech Republic are the preparations MS-222 (tricaine methanesulfonate), 2-phenoxyethanol and clove oil (Kolářová et al. 2006). Clove oil is a dark brown liquid derived by the distillation of stems, leaves and flowers of the Eugenia aromatica and Eugenia caryophylata trees (Soto and Burhanuddin 1995; Kolářrová et al. 2006). Clove oil's active substance is eugenol (4-allyl-2-methoxyphenol), which constitutes $70-90 \%$ of the total weight of the base clove oil. Furthermore, clove oil can consist of other 36 components in lesser amounts (Chaieb et al. 2007). It is the variability of this natural oil, which makes it impossible to define an accurate composition of particular clove oil batches that makes its registration inappropriate. The efficacy and advisability of clove oil for fish anaesthesia has been investigated by many authors in different fish species (Keene et al. 1998; Taylor and Roberts 1999; Grush et al. 2004; Hamáčková et al. 2004; Roubach et al. 2005; Velíšek et al. 2005ab; Cunha and Rosa 2006; Velíšek et al. 2006; Perdikaris et al. 2010). The recommended

Address for correspondence:

MVDr. Petra Doleželová, Ph.D.

University of Veterinary and Pharmaceutical Sciences

Palackého 1-3, 61242 Brno

Czech Republic
Phone: + 420 541562789
Fax: +420 541562790
E-mail: dolezelovap@ vfu.cz
http://www.vfu.cz/acta-vet/actavet.htm 
concentration of clove oil for short-term fish anaesthesia is $30-40 \mathrm{mg} \cdot \mathrm{l}^{-1}$ (Velíšek et al. 2005a).

In our study, we focused on the acute toxicity of clove oil on two aquarium fish species (Danio rerio and Poecilia reticulata) that are recommended as model organisms for toxicity tests in the Organisation for Economic Co-operation and Development Test Guideline 203 (Hrovat et al. 2009). We subsequently compared the sensitivity of these two fish species to identify possible species-specific tolerance to clove oil. The next aim of our study was to compare our results with other authors' findings to prove to which extent the toxicity of clove oil differs in different fish and possibly to warn the users against risks that could arise from species-specific reaction to such anaesthetic.

\section{Materials and Methods}

Clove oil for preparing test solutions was obtained from the company Kulich (Jan Kulich, Hradec Králové/ Říčany, Czech Republic).

Acute toxicity tests followed the OECD 203 Guideline for the Testing of Chemicals (Fish, Acute Toxicity Test) using the semi-static condition with solution replacement after $24 \mathrm{~h}$ to ensure a stable concentration of clove oil in the tested solutions.

Juvenile zebrafish (D. rerio) (age 2 months, length $30 \pm 5 \mathrm{~mm}$, weight $0.3 \pm 0.1 \mathrm{~g})$ and juvenile guppies $(P$. reticulata) (age 2 months, length $25 \pm 5 \mathrm{~mm}$, weight $0.3 \pm 0.1 \mathrm{~g}$ ) were obtained from a stable local commercial dealer. A total number of 260 fish of each species were used. All fish were kept in glass tanks for a minimum of 7 days as an acclimatization period (water temperature $23 \pm 1^{\circ} \mathrm{C}$, with a $12 \mathrm{~h} / 12 \mathrm{~h}$ light/dark cycle) during which they were fed commercial fish pellets. Food was withheld for $24 \mathrm{~h}$ preceding the start of the test. Experimental procedures were in compliance with the national legislation (Act no. 246/1992 Coll. on the protection of animals against cruelty, as amended, and Decree no. 207/2004 Coll. on the protection, breeding and use of experimental animals)

A series of five tests separately for each fish species were performed. Five ascending concentrations of the tested substance $\left(10,15,20,25\right.$, and $30 \mathrm{mg} \cdot l^{-1}$ for both $P$. reticulata and for $D$. rerio) were prepared in 51 tanks by dissolution of clove oil in dilution water of the following quality: $\mathrm{ANC}_{45} 1.0-1.2 \mathrm{mmol} \cdot \mathrm{l}^{-1} ; \mathrm{COD}_{\mathrm{Mn}} 0.8-1.2 \mathrm{mg} \cdot \mathrm{l}^{-1}$; total ammonia below the limit of determination $\left(<0.04 \mathrm{mg} \cdot \mathrm{l}^{-1}\right) ; \mathrm{NO}^{-}{ }^{-1} 1.2-13.5 \mathrm{mg} \cdot \mathrm{l}^{-1} ; \mathrm{NO}_{2}^{-}$below the limit of determination $\left(<0.02 \mathrm{mg} \cdot 1^{-1}\right) ; \mathrm{Cl}^{-1} 10.2-12.5 \mathrm{mg} \cdot 1^{-1} ; \Sigma \mathrm{Ca}+\mathrm{Mg} 14 \mathrm{mg} \cdot \mathrm{l}^{-1}$. Concurrently, the control test with dilution water only was performed. Ten fish of each species from the spare stock were randomly placed into tanks with each concentration of clove oil and control tanks with dilution water. The total length of the acute toxicity tests was $96 \mathrm{~h}$, and the fish were controlled daily. Records of the temperature, $\mathrm{pH}$, and the concentration of oxygen dissolved in the test tanks were noted during the tests. No fish died in the control tanks during the whole experiment.

Medium lethal concentrations (96h LC50) were calculated from the number of fish dying at individual test concentrations over a time period of $96 \mathrm{~h}$ by applying the probit analysis in the software EKO-TOX 5.2. The significance of the difference between LC50 values for zebrafish and guppies was calculated using the nonparametric Mann-Whitney test and Unistat 5.1 software.

\section{Results}

At the determination of LC50 of clove oil in $96 \mathrm{~h}$, the temperature of the experimental bath was $24 \pm 1{ }^{\circ} \mathrm{C}$, the dissolved oxygen concentrations did not drop below $60 \%$ (80-94\%), and the $\mathrm{pH}$ was between 7.64 and 8.33 .

Based on the results of acute toxicity tests on juvenile $D$. rerio, the lethal concentrations in $96 \mathrm{~h}$ varied from $12.1 \mathrm{mg} \cdot \mathrm{l}^{-1}$ to $26.2 \mathrm{mg} \cdot \mathrm{l}^{-1}$ (mean $\pm \mathrm{SD}$ : $18.2 \pm 5.52 \mathrm{mg} \cdot \mathrm{l}^{-1}$ ), whereas in juvenile $P$. reticulata the lethal concentrations varied from $20.8 \mathrm{mg} \cdot \mathrm{l}^{-1}$ to $22.8 \mathrm{mg} \cdot \mathrm{l}^{-1}$ (mean \pm SD: $21.7 \pm 0.8 \mathrm{mg}^{-l^{-1}}$ ). Particular lethal concentrations of clove oil with confidence intervals for each lethal concentration and with mean and standard deviation for zebrafish are shown in Table 1 and for guppy in Table 2.

No significant difference between LC50 values for $D$. rerio and $P$. reticulata was found when applying the non-parametric Mann-Whitney test.

\section{Discussion}

The determination of clove oil acute toxicity is important not only for its usage in fish anaesthesia and the appropriate treatment concentration of clove oil for anaesthetic baths, 
Table 1. Calculated $96 \mathrm{hLC} 50$ values $\left(\mathrm{mg} \cdot \mathrm{l}^{-1}\right)$ of clove oil with $95 \%$ confidence intervals for Danio rerio.

\begin{tabular}{lcc}
\hline Test series & LC50 $\mathrm{mg}^{-1} \mathrm{I}^{-1}$ & 95\% confidence interval \\
\hline 1 & 12.1 & $10.8-14.2$ \\
2 & 14.3 & $11.5-17.8$ \\
3 & 17.8 & $16.1-19.4$ \\
4 & 20.5 & $16.0-24.2$ \\
5 & 26.2 & $20.9-30.7$ \\
\hline Mean LC50 & 18.2 & \\
Standard deviation & 5.52 & \\
\hline
\end{tabular}

Table 2. Calculated $96 \mathrm{hLC} 50$ values $\left(\mathrm{mg} \cdot \mathrm{l}^{-1}\right)$ of clove oil with $95 \%$ confidence intervals for Poecilia reticulata.

\begin{tabular}{lcc}
\hline Test series & LC50 $\mathrm{mg} \cdot \mathrm{l}^{-1}$ & 95\% confidence interval \\
\hline 1 & 21.8 & $19.9-23.6$ \\
2 & 22.1 & $19.3-24.6$ \\
3 & 20.8 & $16.3-24.5$ \\
4 & 22.8 & $16.4-27.8$ \\
5 & 21.1 & $12.4-27.3$ \\
\hline Mean LC50 & 21.7 & \\
Standard deviation & 0.8 & \\
\hline
\end{tabular}
glanis L.) with an $96 \mathrm{hLC} 50$ value of $18.4 \mathrm{mg} \cdot \mathrm{l}^{-1}$ (Velíšek et al. 2006). On the other hand, a lower lethal concentration $96 \mathrm{hLC} 50$ of $14.1 \mathrm{mg} \cdot \mathrm{l}^{-1}$ was reported in rainbow trout (Oncorhynchus mykkis) by the same author (Velíšek et al. 2005a). Keene et al. (1998) obtained a similar result in rainbow trout considering that the estimated $96 \mathrm{hLC} 50$ for eugenol (active form of clove oil) was found to be approximately $10 \mathrm{mg} \cdot \mathrm{l}^{-1}$. According to these findings, rainbow trout showed the highest sensitivity to clove oil, which corresponds with the commonly known fact that salmonids are more sensitive to environmental pollutants than other fish species. Zebrafish, carp, catfish and guppy showed comparable tolerance to acute toxicity of clove oil.

One of the criteria that proper anaesthetic in fish should meet is its safety at treatment concentrations (Marking and Meyer 1985). The recommended treatment concentrations vary according to fish species, fish size, exposure time, bath quality and temperature. Roubach et al. (2005) found that exposure of tambaqui (Colossoma macropomum) to $65 \mathrm{mg} \cdot \mathrm{l}^{-1}$ of eugenol was sufficient to induce an anaesthetic state, and recovery time was similar for dosages up to $100 \mathrm{mg} \cdot \mathrm{l}^{-1}$. Exposure to $65 \mathrm{mg} \cdot \mathrm{l}^{-1}$ for up to $30 \mathrm{~min}$ did not cause fish mortality. There was no mortality in tambaqui at doses of $135 \mathrm{mg} \cdot \mathrm{l}^{-1}$ (exposure duration was not reported).

The rainbow trout is the most sensitive fish species, with LC50 values for clove oil of 81.1 $\mathrm{mg} \cdot \mathrm{l}^{-1}$ for $10 \mathrm{~min}$ (Velís š et al. 2005a) or $65 \mathrm{mg} \cdot \mathrm{l}^{-1}$ for an exposure time of $30 \mathrm{~min}$ (Keene et al. 1998). Taylor and Roberts (1999) determined the median lethal concentration for 10-min exposure for rainbow trout at $250 \mathrm{mg} \cdot \mathrm{l}^{-1}$, which means about $3 \times$ higher than the result obtained by Velíšek et al. (2005a). Comparable values were reported by the same authors for chinook salmon (Oncorhynchus tshawytscha) at $62 \mathrm{mg} \cdot \mathrm{l}^{-1}$, higher for coho salmon $(O$. kisutch) at $96 \mathrm{mg} \cdot \mathrm{l}^{-1}$ and for white sturgeon (Acipenser transmontanus) at $526 \mathrm{mg} \cdot \mathrm{l}^{-1}$. Acute toxicity values of clove oil expressed as $10 \mathrm{minLC} 50$ were $74.3 \mathrm{mg} \cdot \mathrm{l}^{-1}$ for carp (Velíšek et al. 2005b) and $76.70 \mathrm{mg} \cdot \mathrm{l}^{-1}$ for the European catfish (Velís ek et al. 2006).

Perdikaris et al. (2010) evaluated the size-relative effectiveness of clove oil for rainbow trout and goldfish (Carassius auratus). Rainbow trout exhibited a more rapid induction 
time compared to goldfish. A size-relative difference in induction time was observed in goldfish (the larger the fish, the more time needed for induction). Cunha and Rosa (2006) compared induction and recovery times of seven tropical fish species in different concentrations of clove oil. They proved species-specific dependent variation in induction and recovery times.

The interspecies differences in anaesthetic sensitivity are connected to the heterogeneous metabolism of individual fish species and to differences in environmental test conditions (Mácová et al. 2008). Another possibility for the different LC50 values stated by different authors is the variability of the clove oil composition used. However, Taylor and Roberts (1999), who tested the effectiveness (time to loss of equilibrium and immobilization) of clove oil from different sources, did not prove a difference in dependence on the tested clove oil.

In summary, clove oil has been proven by many authors to be an efficient anaesthetic for a variety of fish. However, it is important to carry out the sensibility test before each use of this anaesthetic to prevent possible fish damage during anaesthesia bath and to recognize possible differences in fish sensitivity.

\section{Acknowledgements}

This work has been conducted with the support of MSM Project no. 6215712402 Veterinary Aspects of Food Safety and Quality.

\section{References}

Chaieb K, Hajlaoui H, Zmantar T, Kahla-Nakbi AB, Rouabhia M, Mahdouani K, Bakhrout A 2007. The chemical composition and biological activity of clove essential oil, Eugenia caryophyllata (Syzigium aromaticum L. Myrtaceae): A short review. Phytother Res 21: 501-506

Cunha FEA, Rosa IL 2006: Anaesthetic effects of clove oil on seven species of tropical reef teleosts. J Fish Biol 69: $1504-1512$

Hamáčková J, Lepičová A, Kozák P, Stupka Z, Kouřil J, Lepič P 2004. The efficacy of various anaesthetics in tench (Tinca tinca L.) related to water temperature. Vet Med - Czech 49: 467-472

Hrovat M, Segner H, Jeram S 2009. Variability of in vivo fish acute toxicity data. Regul Toxicol Pharm 54: 294300

Grush J, Noakes DLG, Moccia RD 2004. The efficacy of clove oil as an anesthetic for the zebrafish, Danio rerio (Hamilton). Zebrafish 1: 46-53

Keene JL, Noakes DLG, Moccia RD, Soto CG 1998. The efficacy of clove oil as an anaesthetic for rainbow trout, Oncorhynchus mykiss (Walbaum). Aquac Res 29: 89-101

Kolářová J, Svobodová Z, Nepejchalová L, Velíšek J, Piačková V 2006. Anaesthesia of fish in Czech Republic. Bull VÚRH Vodňany (In Czech) 42: 105-108

Mácová S, Doleželová P, Pištěková V, Svobodová Z, Bedáňová I, Voslářová E 2008. Comparison of acute toxicity of 2-phenoxyethanol and clove oil to juvenile and embryonic stages of Danio rerio. Neuroendocrinol Lett 29: 680-684

Marking LL, Meyer FP 1985. Are better anesthetics needed in fisheries? Fisheries 10: 2-5

Perdikaris C, Nathanailides C, Gouva E, Gabriel UU, Bitchava K, Athanasopoulou F, Paschou A, Paschos I 2010. Size-relative effectiveness of clove oil as an anaesthetic for rainbow trout (Oncorhynchus mykkis Walbaum, 1792) and goldfish (Carassius auratus Linnaeus, 1758). Acta Vet Brno 79: 481-490

Roubach R, Gomes LC, Fonseca FAL, Val AL 2005. Eugenol as an efficacious anaesthetic for tambaqui, Colossoma macropomum (Cuvier). Aquac Res 36: 1056-1061

Soto CG, Burhanuddin 1995. Clove oil as a fish anaesthetic for measuring length and weight of rabbitfish (Siganus lineatus). Aquaculture 136: 149-152

Taylor PW, Roberts SD 1999. Clove oil: An alternative anaesthetic for aquaculture. N Am J Aquacult 61: $150-155$

Velíšek J, Svobodová Z, Piačková V 2005a. Effetc of clove oil anaesthesia on rainbow trout (Oncorhynchus mykiss). Acta Vet Brno 74: 139-146

Velíšek J, Svobodová Z, Piačková V, Groch L, Nepejchalová L 2005b. Effects of clove oil anaesthesia on common carp (Cyprinus carpio L.). Vet Med - Czech 50: 269-275

Velíšek J, Wlasow T, Gomulka P, Svobodová Z, Novotný L, Ziomek E 2006. Effects of clove oil anaesthesia on european catfish (Silurus glanis L.). Acta Vet Brno 75: 99-106 